\title{
Correction to: Language and imagined Gesellschaft: Émile Durkheim's civil-linguistic nationalism and the consequences of universal human ideals
}

\author{
Mitsuhiro Tada ${ }^{1}$ \\ Published online: 15 February 2021 \\ (C) Springer Nature B.V. 2021
}

\section{Correction to: Theory and Society https://doi.org/10.1007/s11186-020-09394-1}

The article Language and imagined Gesellschaft: Émile Durkheim's civil-linguistic nationalism and the consequences of universal human ideals, written by Mitsuhiro Tada, was originally published Online First without Open Access. After publication in volume 49, issue 4, page 597-630 the author decided to opt for Open Choice and to make the article an Open Access publication. Therefore, the copyright of the article has been changed to (C) The Author(s) 2021 and the article is forthwith distributed under the terms of the Creative Commons Attribution.

This article is licensed under a Creative Commons Attribution 4.0 International License, which permits use, sharing, adaptation, distribution and reproduction in any medium or format, as long as you give appropriate credit to the original author(s) and the source, provide a link to the Creative Commons licence, and indicate if changes were made.

The images or other third party material in this article are included in the article's Creative Commons licence, unless indicated otherwise in a credit line to the material. If material is not included in the article's Creative Commons licence and your intended use is not permitted by statutory regulation or exceeds the permitted use, you will need to obtain permission directly from the copyright holder.

The online version of the original article can be found at https://doi.org/10.1007/s11186-020-09394-1

Mitsuhiro Tada

mtada@kumamoto-u.ac.jp

1 Faculty of Humanities and Social Sciences, Kumamoto University, 40-1, Kurokami

2-chome,Chuo-ku, Kumamoto 860-8555, Japan 
To view a copy of this licence, visit http://creativecommons.org/licenses/by/4.0/.

Open Access This article is licensed under a Creative Commons Attribution 4.0 International License, which permits use, sharing, adaptation, distribution and reproduction in any medium or format, as long as you give appropriate credit to the original author(s) and the source, provide a link to the Creative Commons licence, and indicate if changes were made. The images or other third party material in this article are included in the article's Creative Commons licence, unless indicated otherwise in a credit line to the material. If material is not included in the article's Creative Commons licence and your intended use is not permitted by statutory regulation or exceeds the permitted use, you will need to obtain permission directly from the copyright holder. To view a copy of this licence, visit http://creativecommons.org/licenses/by/4.0/.

Publisher's note Springer Nature remains neutral with regard to jurisdictional claims in published maps and institutional affiliations. 